\title{
Taxonomic and palaeoecological review of the Soricidae (Mammalia) fauna from the late Early Pleistocene Somssich Hill 2 locality (Villány Hills, Southern Hungary)
}

\author{
Dániel Bot Ka \& Lukács MÉszÁros
}

Eötvös Loránd University, Department of Palaeontology, H-1117 Budapest, Pázmány Péter sétány 1/C, Hungary. E-mails:botkadani@gmail.com,lgy.meszaros@gmail.com

\begin{abstract}
The present paper is the concluding part of the series describing the Soricidae fauna of the late Early Pleistocene Somssich Hill 2 locality, Southern Hungary. The assemblage includes 9 shrew forms: 3 Sorex, 2 Crocidura, 2 Beremendia, 1 Asoriculus, and 1 Neomys species. The taxonomic results of the study are summarized, and some new ecological conclusions drawn from the layer-bylayer overview of the specific composition of the fauna are presented here. The forms of cold grassy vegetation dominate in most of the strata, but the indicators of warm grasslands also appear in some layers. The appearance of forest species in most layers correlates with the presence of aquatic shrews. The ratio of cold and warm-indicating species varies in the layers, but dominance of cold indicators decreases in the second half of the succession, while the number of forest and warm indicators increases. With 2 figures and 2 tables.
\end{abstract}

Key words - late Early Pleistocene, palaeoecology, palaeoenvironment, Somssich Hill, Soricidae

\section{INTRODUCTION}

The present article is the final chapter of the study published in this journal on the late Early Pleistocene Soricidae fauna of the Somssich Hill 2 locality in Villány Hills, Southern Hungary. This site, discovered by Dénes Jánossy and György Topál in 1974, is a sediment-filled karst fissure in the Jurassic limestone of the Villány Hills. The infilling sediment was excavated by them in 50 layers between 1974 and 1984. Their excavation yielded rich fossil fauna, which was elaborated by the cooperative research group of the Hungarian Academy of Sciences, the Hungarian Natural History Museum, and the Eötvös Loránd University (OTKA K104506 research project, during the 2013-2017 period, project leader: Piroska Pazonyi) in the Department of Palaeontology and Geology of the Hungarian Natural History Museum (Pazony et al. 2018). Description of the locality and history of the investigation of its fossil material are given by ВоткA 
\& MÉszÁros (2014b). Based on the stratigraphic ranges of the mammal species, the fauna was correlated with the Mimomys savini-Mimomys pusillus Biozone in the late Early Pleistocene Biharian Age (MQ1) by PAzOnYi et al. (2018).

The fossil assemblage of the Somssich Hill 2 site included 5 shrew genera with 9 species, which were identified and published in the earlier issues of the present journal by BotKA \& MÉszÁros (2014b: Beremendia; 2015: Crocidura; 2016: Sorex; 2017: Asoriculus and Neomys).

Botka \& Mészáros (2014a), Mészáros (2015), MÉszáros \& BotKa 2017, and PAZONY i et al. $(2016 a, 2018)$ have already published some preliminary results on the palaeoecology of Somssich Hill 2 shrews, but a detailed picture of the habitat could not be drawn without studying the complete soricid assemblage.

A systematic review of the elaborated Soricidae fauna with the list of new taxonomic results is shown in the part "Taxonomy". The morphological terms are used after REUMER (1984) in these descriptions. Overview of the specific composition of the shrew community by layers is presented in the ecological part of this article. It resulted some new ecological consequences that differ in some details from the hypotheses shown in preliminary reports.

The detailed data of the environmental marker shrew groups are shown by layers in Table 1. The number of individuals of different species belonging to one genus, which indicate the same environment, is only shown under the name of the genus. If the species within a genus preferred different environments, we separately listed their numbers of individuals.

\section{TAXONOMY}

Taxonomic review - The very rich Soricidae fauna of Somssich Hill 2 locality contains 5086 specimens with 1040 minimum number of individuals. The studied material is stored in the Department of Palaeontology and Geology of the Hungarian Natural History Museum, Budapest. The assemblage includes 9 shrew forms: 3 Sorex, 2 Crocidura, 2 Beremendia, 1 Asoriculus, and 1 Neomys species. Their classification with the specimen number (n) and minimum number of individuals (MNI) data are listed below.

Phylum Vertebrata Linnaeus, 1758

Classis Mammalia Linnaeus, 1758

Order Eulipotyphla Waddell et al., 1999

Family Soricidae Fischer von Waldheim, 1814

Subfamily Soricinae Fischer von Waldheim, 1814

Tribe Soricini Fischer von Waldheim, 1814

Genus Sorex Linnaeus, 1758 
Sorex minutus Linnaeus, 1766 - n: 380; MNI: 104

Sorex runtonensis Hinton, $1911-\mathrm{n}$ : 4069; MNI: 700

Sorex (Drepanosorex) savini Hinton, 1911 - n: 200; MNI: 65

Tribe Neomyini Matschie, 1909

Genus Asoriculus Kretzoi, 1959

Asoriculus gibberodon (Petényi, 1864) - n: 7; MNI: 6

Genus Neomys Kaup, 1829

Neomys newtoni Hinton, 1911 - n: 42; MNI: 20

Tribe Beremendiini Reumer, 1984

Genus Beremendia Kormos, 1934

Beremendia fissidens (Petényi, 1864) - n: 169; MNI: 61

Beremendia minor Rzebik-Kowalska, 1976 - n: 11; MNI: 8

Subfamily Crocidurinae Milne-Edwards, 1874

Genus Crocidura Wagler, 1832

Crocidura kornfeldi Kormos, 1934 - n: 12; MNI: 10

Crocidura obtusa Kretzoi, 1938 - n: 15; MNI: 13

Crocidura sp. (kornfeldi or obtusa) - n: 181; MNI: 53

Taxonomic results - The present investigation on the Somssich Hill 2 fossil material has resulted taxonomically in three Soricidae groups.

1. The specially adapted genus Beremendia occurs with two species in the Carpathian Basin. The bigger B. fissidens described by PetÉNYI (1864) and the smaller B. minor discovered by RzEBI K-KowALS KA (1976) are well distinguished by size of the upper and lower molars. Separation was supported by the morphometric analysis made on the $\mathrm{M}_{2}$ length and width of the two forms by BоTKA \& MÉszÁros (2014b). They emended the differential characters between the two species with some morphological characteristics, the most important one of which was in the third lower molar. B. fissidens has basined $\mathrm{M}_{3}$ talonid with straight posterior margin (hypolophid) and the entoconid is lower than that one of the smaller species. Contrarily, $B$. minor has a more reduced, not basined $\mathrm{M}_{3}$ talonid with rounded posterior margin and high entoconid. 
2. Specimens of the Sorex (Drepanosorex) savini-margaritodon group are reported from several localities of the European Early and Middle Pleistocene. Sorex savini was described by HINTON (1911) and Kormos (1930) distinguished another species for a similar form as $S$. margaritodon on the basis of its smaller size than the previous one. ВоткA \& MÉszáros (2016) demonstrated that the measurements of the two forms overlap and the tiny differences between them may be the consequences of intraspecific variability. Hence, they thought that

Table 1. MNI of shrew groups that indicate different habitats, by layers (A) of the Somssich Hill 2 locality; Open water indicator: Sorex (Drepanosorex) savini (B) and Neomys (C); Aquatic or opportunist: Beremendia (D); forested or bushy vegetation: Sorex minutus (E) and Asoriculus (F); Cold grassland: Sorex runtonensis (G); Open environment in warm climate: Crocidura $(\mathrm{H})$

\begin{tabular}{cccccccc}
\hline A & B & C & D & E & F & G & H \\
\hline 1 & - & - & - & - & - & 1 & - \\
2 & - & - & 1 & - & - & 1 & - \\
3 & - & - & 1 & - & - & 1 & - \\
4 & 1 & 1 & 3 & 3 & - & 15 & 5 \\
5 & 2 & 2 & 9 & 3 & - & 20 & 11 \\
6 & 1 & - & 2 & 1 & - & 10 & 3 \\
7 & 2 & - & 1 & 1 & - & 8 & 2 \\
8 & 2 & - & 1 & - & 1 & 10 & 3 \\
9 & 1 & - & 1 & 1 & - & 4 & 1 \\
10 & - & - & - & 1 & - & 6 & 4 \\
11 & 1 & - & 2 & - & - & 4 & 3 \\
12 & 1 & - & 2 & - & - & 11 & 3 \\
13 & 2 & - & 4 & 3 & - & 15 & 3 \\
14 & - & - & 3 & 13 & - & 7 & 3 \\
15 & 1 & 1 & 5 & 3 & - & 8 & 1 \\
16 & 1 & - & - & 2 & - & 4 & 2 \\
17 & - & - & - & - & - & 2 & - \\
18 & - & - & 1 & 1 & - & 3 & 1 \\
19 & - & - & - & 1 & - & 4 & - \\
20 & - & - & 1 & - & - & 2 & 1 \\
21 & 1 & - & - & 1 & 1 & 1 & - \\
22 & 2 & 2 & 2 & 3 & - & 16 & 2 \\
23 & 2 & - & - & 2 & - & 14 & - \\
24 & 5 & 1 & 3 & 5 & - & 7 & 1 \\
25 & 2 & 1 & 3 & 4 & 1 & 11 & 4 \\
\hline & & & & & & &
\end{tabular}

\begin{tabular}{cccccccc}
\hline $\mathrm{A}$ & $\mathrm{B}$ & $\mathrm{C}$ & $\mathrm{D}$ & $\mathrm{E}$ & $\mathrm{F}$ & $\mathrm{G}$ & $\mathrm{H}$ \\
\hline 26 & - & - & 1 & 1 & - & 9 & 1 \\
27 & - & 1 & 4 & 2 & 1 & 14 & - \\
28 & 1 & 1 & 4 & 4 & 1 & 31 & - \\
29 & 2 & - & 1 & 3 & - & 25 & 3 \\
30 & 1 & - & 3 & 3 & - & 15 & 3 \\
31 & 2 & 1 & 3 & 1 & - & 24 & 2 \\
32 & 1 & 1 & 4 & 2 & - & 24 & - \\
33 & 1 & 2 & 3 & 1 & - & 12 & 1 \\
34 & 1 & - & 1 & - & - & 9 & - \\
35 & 2 & - & 2 & 2 & - & 23 & - \\
36 & 2 & 1 & 3 & 3 & - & 19 & 1 \\
37 & 1 & - & 1 & 1 & - & 12 & 1 \\
38 & 1 & - & 2 & 3 & - & 10 & 2 \\
39 & 3 & 1 & 2 & 3 & - & 21 & 1 \\
40 & 2 & 1 & 3 & 5 & - & 19 & - \\
41 & 2 & 1 & 2 & 3 & - & 26 & 2 \\
42 & 3 & - & 1 & 3 & - & 33 & 1 \\
43 & 2 & - & 2 & 4 & - & 31 & 1 \\
44 & 1 & 1 & 2 & 4 & - & 37 & 1 \\
45 & 2 & 1 & 2 & 4 & 1 & 25 & 1 \\
46 & 5 & - & 1 & 1 & - & 40 & 2 \\
47 & 1 & - & 1 & 2 & - & 21 & - \\
48 & 2 & - & - & 1 & - & 20 & - \\
49 & - & - & - & 1 & - & 11 & - \\
50 & - & - & 1 & 2 & - & 5 & - \\
\hline & & & & & &
\end{tabular}


Sorex (Drepanosorex) margaritodon Kormos, 1930 is a junior synonym of Sorex (Drepanosorex) savini Hinton, 1911, thus the earlier $S$. (D.) savini is the valid name. This hypothesis is supported by the fact that the areas of the two species do not separate from each other in time and space.

3. The rich Crocidura material of Somssich Hill 2 site provided important data to the distinction of the Early Pleistocene white-toothed shrew Crocidura obtusa from the coeval C. kornfeldi. Latter was discovered by Kormos (1934), while C. obtusa was originally described by Kretzor (1938) as a new species. Because Kretzoi's description was not properly detailed, the later authors separated the two species mainly on the basis of the size of the teeth. The morphometric studies by BotKA \& MÉszÁros (2015) revealed that the differentiation of the isolated teeth of C. kornfeldi and C. obtusa is unreal based on the measurements only. They emended the original diagnosis according to the observations of RzeBiK-Kowals Ka (2000) and their studies on the Somssich Hill 2 material with some morphological characters, mainly in the mandibular ramus.

\section{PALAEOECOLOGY}

The elements of Somssich Hill 2 Soricidae fauna refer to several habitats. Sorex minutus and Asoriculus gibberodon indicate a humid environment with a good covering of vegetation (REUMER 1984; RZEBIK-KowalsKa 2003). Crocidura prefers warm climate and dry terrains, with more or less open grasslands. We have to look on Sorex runtonensis as an indicator of arid and relatively open environment, but it could live in especially cold climate (Osipova et al. 2006). Neomys newtoni is considered as indicator of open water bodies due to its relationship with recent water shrews (e.g. Neomys fodiens). The presence of river or lakeside is marked by Sorex (Drepanosorex) savini as well (REUMER 1984; MAUL \& PARFITT 2010). Beremendia is ranged to the "water-indicator or opportunist" group (see PAZONYi et al. 2016b) in our ecotype reconstruction (Table 2).

Table 2. Frequency of shrew groups that indicate different habitats in the Somssich Hill 2 locality (MNI)

\begin{tabular}{lcc}
\hline Ecotype & Soricidae form & $\%$ \\
\hline Humid forest or bush & Sorex minutus & 10 \\
& Asoriculus & 1 \\
Cold grassland & Sorex runtonensis & 67 \\
Warm grassland & Crocidura & 7 \\
Open water body & Sorex $($ D.) savini & 6 \\
& Neomys & 2 \\
Aquatic or opportunist & Beremendia & 7 \\
\hline
\end{tabular}


Examining the ecological composition of the complete Soricidae fauna, the dominance of the cold steppe indicator Sorex runtonensis is clearly conspicuous (Fig. 1). Asoriculus gibberodon and Sorex minutus, which prefer closed forests and scrubland environment, occur much less frequently. Their frequency is approximately the same as that of aquatic shrews (S. (D.) savini, Neomys newtoni, and perhaps Beremendia). Crocidura species - living in warm grassy areas - is hardly present in the assemblage.

It can be assumed that the vegetation was mainly open in the surroundings of the site and the climate was rather cold than warm for most of the time. Woodland or scrubland areas could be mostly related to open water surfaces.

Drawn the layer-by-layer overview on the specific composition of the fauna (Fig. 2), we can see different ratios in the layers. The forms of cold grassy vegetation dominate in most of the strata, but the indicators of warm grasslands, with lower frequency, also appear in many layers. The appearance of forest species in most layers correlates with the presence of aquatic shrews. Ratio of cold and warm-indicating species varies in the layers, but dominance of cold indicators decreases in the second half of the succession, while the number of forest and warm indicators increases.

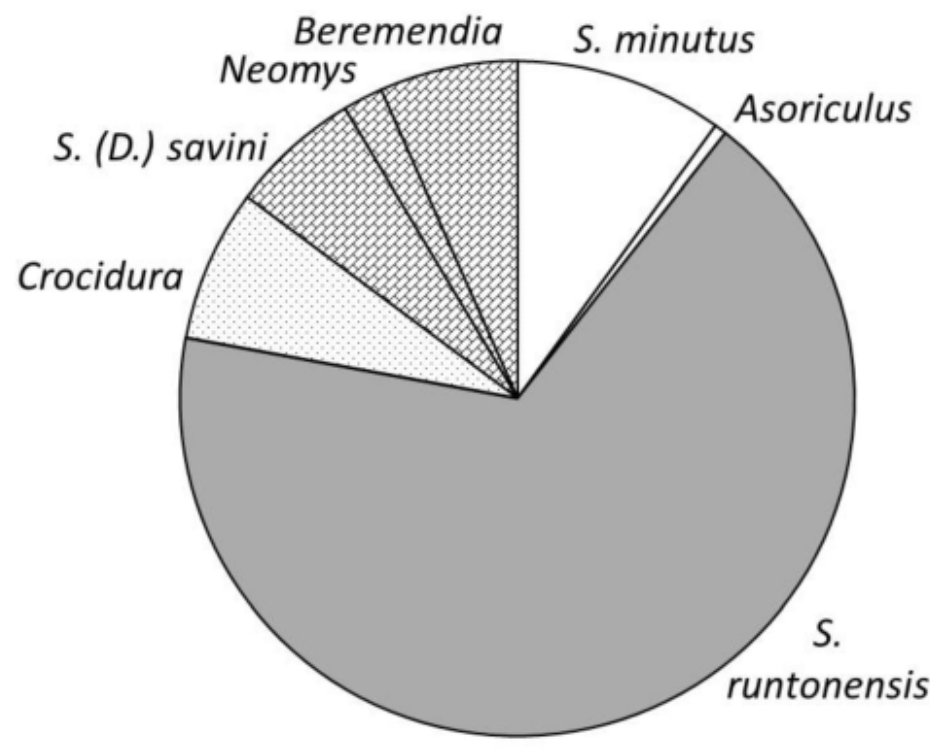

Fig. 1. Frequency of the indicators of different habitats in the Somssich Hill 2 locality (MNI). Humid climate with forested or bushy vegetation: Sorex minutus and Asoriculus; Cold grassland: Sorex runtonensis; Open environment in warm climate: Crocidura; Open water indicators: Sorex (Drepanosorex) savini and Neomys; Aquatic or opportunist: Beremendia 


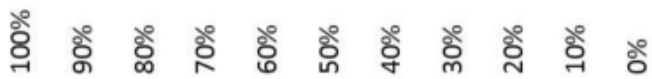

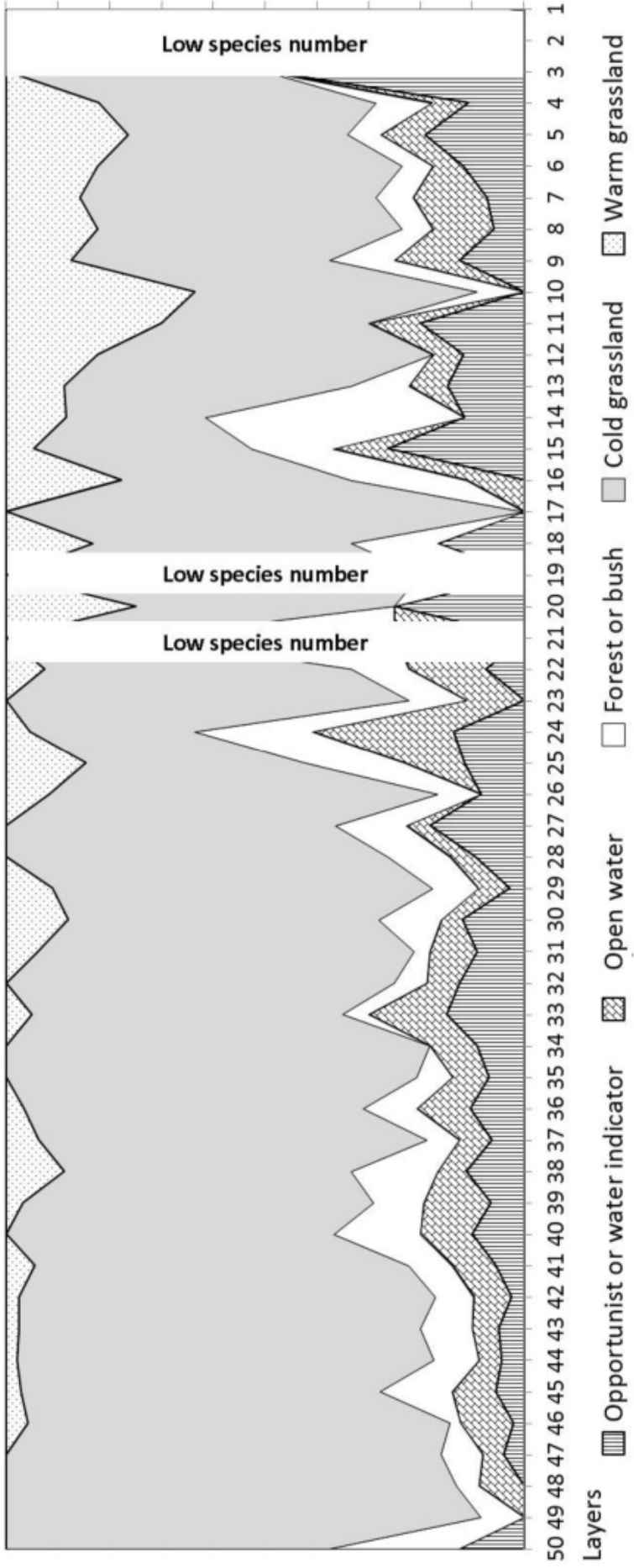


It should be noted that this detailed review somewhat modifies the earlier reconstructions, in which the ecological differences within the genus Sorex were not considered (e.g. MÉszáros 2015). The most important novelty in this article compared to the previous ones is that, based on $S$. runtonensis, we can now detect cold steppes in those layers, where we previously assumed closed vegetation due to the general presence of Sorex.

The Somssich Hill 2 soricid assemblage contains mainly a late Early Pleistocene fauna, however, it yielded a few shrew specimens that suggest an older age, namely the late Villányian (MN17) (PAzONY et al. 2018). Asoriculus gibberodon and Beremendia minor are these elements with a very low number of individuals, referring to occasional redepositional processes.

Acknowledgements - The work was supported by the Hungarian Scientific Research Fund (OTKA K104506 project). The authors are indebted to the members of the OTKA Research Team, mainly to Piroska Pazonyi (project leader), Zoltán Szentesi, Mihály Gasparik, and Attila Virág for their useful help and valuable suggestions. Special thanks to Piroska Pazonyi for her useful reviewer comments.

\section{REFERENCES}

Bot KA D. \& MÉszÁros L. 2014a: A Somssich-hegy 2-es lelőhely alsó-pleisztocén Soricidae faunája. [The Lower Pleistocene Soricidae fauna of the Somssich Hill 2 locality.] - In: BosNA KofF M. \& Dulai A. (eds): Program, Elöadáskivonatok, Kirándulásvezetö, 17. Magyar Öslénytani Vándorgyülés, Győr, pp. 10-11. (in Hungarian)

Bot KA D. \& MÉszÁros L. 2014b: Beremendia (Mammalia, Soricidae) remains from the late Early Pleistocene Somssich Hill 2 locality (Southern Hungary) and their taxonomic, biostratigraphical, palaeoecological and palaeobiogeographical relations. - Fragmenta Palaeontologica Hungarica 31: 83-115. https://doi.org/10.17111/FragmPalHung.2014.31.83

Botka D. \& MÉszÁros L. 2015: Crocidura (Mammalia, Soricidae) remains from the late Early Pleistocene Somssich Hill 2 locality (Villány Hills, Southern Hungary). - Fragmenta Palaeontologica Hungarica 32: 67-98. https://doi.org/10.17111/FragmPalHung.2015.32.67

Bot Ka D. \& Mészáros L. 2016: Sorex (Mammalia, Soricidae) remains from the late Early Pleistocene Somssich Hill 2 locality (Villány Hills, Southern Hungary). - Fragmenta Palaeontologica Hungarica 33: 135-154. https://doi.org/10.17111/FragmPalHung.2016.33.135

Bot Ka D. \& MÉszáros L. 2017: Asoriculus and Neomys (Mammalia, Soricidae) remains from the late Early Pleistocene Somssich Hill 2 locality (Villány Hills, Southern Hungary). - Fragmenta Palaeontologica Hungarica 34: 105-125. https://doi.org/10.17111/FragmPalHung.2017.34.105

Hinton M. A. C. 1911: I.-The British Fossil Shrews. - Geological Magazine (Decade V) 8(12): 529-539.

Kormos T. 1930: Új adatok a püspökfürdői Somlyóhegy preglaciális faunájához. [New data of the praeglacial fauna of Somlyó Hill, Betfia.] - Állattani Közlemények 27: 40-62. 
Kormos T. 1934: Neue Insektenfresser, Fledermäuse und Nager aus dem Oberpliozän der Villányer Gegend. - Földtani Közlöny 64(1): 296-321.

Kretzoi M. 1938: Die Raubtiere von Gombaszög nebst einer übersicht der Gesamtfauna (Ein Beitrag zur Stratigraphie des Altquartaers). - Annales historico-naturales Musei nationalis hungarici 31: 88-157.

Maul L. C. \& Parfitt S. A. 2010: Micromammals from the 1995 Mammoth Excavation at West Runton, Norfolk, UK: Morphometric data, biostratigraphy and taxonomic reappraisal. Quaternary International 228(1): 91-115. https://doi.org/10.1016/j.quaint.2009.01.005

MÉszáros L. 2015: Palaeoecology of the Early Pleistocene Somssich Hill 2 locality (Hungary) based on Crocidura and Sorex (Mammalia, Soricidae) occurrences. - Hantkeniana 10: $147-152$.

MÉszÁRos L. \& Bot KA D. 2017: A Somssich-hegy 2-es lelőhely Soricidae faunájának taxonómiája és paleoökológiája. [Taxonomy and palaeoecology of the Soricidae fauna of the Somssich Hill 2 locality.] - In: Virág A. \& Bosna Koff M. (eds): Program, Elöadáskivonatok, Kirándulásvezetö, 20. Magyar Öslénytani Vándorgyülés, Tata-Tardos, pp. 27-28. (in Hungarian)

Osipova V. A., Rzebik-Kowalska B. \& Zaitsev M. V. 2006: Intraspecific variability and phylogenetic relationships of the Pleistocene shrew Sorex runtonensis (Soricidae). - Acta Theriologica 51(2): 129-138.

Pazonyi P., Mészáros L., Szentesi Z., Gaspari k M., Virág A., Gere K., Mészáros R., BotKA D., Braun B. \& STRICZKy L. 2016a: Taxonomical, taphonomical and paleoecological aspects of a late Early Pleistocene vertebrate fauna from the Somssich Hill 2 site (South Hungary). - In: Holwerda F., Madern A., Voeten D., van Heteren A., Meijer H. \& DEN OUden N. (eds): XIV Annual Meeting of the European Association of Vertebrate Palaeontologists, Programme and Abstract Book, Koninklijke Nederlandse Akademie van Wetenschappen, Haarlem, The Netherlands, p. 36.

Pazonyi P., Mészáros L., Hír J. \& Szentesi Z. 2016b: The lowermost Pleistocene rodent and soricid (Mammalia) fauna from Beremend 14 locality (South Hungary) and its biostratigraphical and palaeoecological implications. - Fragmenta Palaeontologica Hungarica 33: 99-134. https://doi.org/10.17111/FragmPalHung.2016.33.99

Pazonyi P., Virág A., Gere K., Botfalvai G., Sebe K., Szentesi, Z. Mészáros L., Bot ka D., GASPARIK M. \& Korecz L. 2018: Sedimentological, taphonomical and palaeoecological aspects of the late early Pleistocene vertebrate fauna from the Somssich Hill 2 site (South Hungary). - Comptes Rendus Palevol 17(4-5): 296-309. https://doi.org/10.1016/j.crpv.2017.06.007

PetéNYi S. J. 1864: A beremendi mészkőbánya természetrajz- és őslénytanilag leírva. Hátrahagyott munkái. [Geological and palaeontological description of the Beremend limestone quarry. Posthumus works.] - Magyar Tudományos Akadémia kiadása 1: 35-81.

Reumer J. W. F. 1984: Ruscinian and early Pleistocene Soricidae (Insectivora, Mammalia) from Tegelen (The Netherlands) and Hungary. - Scripta Geologica 73: 1-173.

Rzebik-Kowalska B. 1976: The Neogene and Pleistocene insectivores (Mammalia) of Poland. III. Soricidae: Beremendia and Blarinoides. - Acta Zoologica Cracoviensia 22(12): 359-385.

RzebiK-Kowals Ka B. 2000: Insectivora (Mammalia) from the Early and early Middle Pleistocene of Betfia in Romania. I. Soricidae Fischer von Waldheim, 1817. - Acta Zoologica Cracoviensia 43(1-2): 1-53.

Rzebik-Kowalska B. 2003: Distribution of shrews (Insectivora, Mammalia) in time and space. - Deinsea 10(1): 499-508. 